\title{
HEALTH ADJUSTED GDP (HAGDP) MEASURES OF THE RELATIONSHIP BETWEEN ECONOMIC GROWTH, HEALTH OUTCOMES AND SOCIAL WELFARE
}

\author{
MATTHEW CLARKE \\ SARDAR M. N. ISLAM
}

CESIFO WORKING PAPER NO. 1002

CATEGORY 2: Public CHOICE

JULY 2003

Presented at CESifo Conference on Health and Economic Policy, June 2003

\footnotetext{
An electronic version of the paper may be downloaded

- from the SSRN website: www.SSRN.com

- from the CESifo website: www.CESifo.de
} 


\title{
HeAlth AdJusted GDP (HAGDP) MEASURES OF THE RELATIONSHIP BETWEEN ECONOMIC GROWTH, HEALTH OUTCOMES AND SOCIAL WELFARE
}

\begin{abstract}
Welfare economic analysis of health issues and policies can provide well balanced orderings of the state of the economy. This paper provides an innovative framework for welfare economic analysis of the relationships between economic growth, health outcomes and social welfare for both a developing and a developed country. Economic growth can increase health outcomes and social welfare but its influence is limited by biological laws. Further, achieving economic growth may have negative externalities which reduce health outcomes (particularly when biological health limits are reached). A new health adjusted GDP indicator to investigate the relationship between economic growth, health outcomes and social welfare in both a developing and developed country using social choice perspectives is developed in this paper. This new approach to social welfare analysis is also based on cost-benefit analysis and systems analysis and is called the social choice approach. The importance of good health is crucial when determining social welfare. The major limitation of many health-based indicators is that they can fail to adequately consider social welfare issues, such as equity and efficiency. Social choice theory allows optimal health outcomes to be fully considered in terms of equity and efficiency when determining the impact of economic growth on social welfare. Social choice theory incorporates the various "social concerns" that are not adequately captured using individual preference satisfaction techniques. This paper analyses the health outcomes resulting from economic growth (costs and benefits) using Thailand and Australia as case studies, from 1975 to 1999. Two health adjusted gross domestic product (HAGDP) indices are prepared in this paper by adjusting GDP to reflect the social welfare impacts of achieving economic growth on health outcomes. This paper shows that stark differences exist between the relationships of economic growth, health outcomes and social welfare between developing and developed countries - economic growth has limited net health outcome benefits at certain stage of a countries development, yet is very important at other times. This suggests that utilising the social choice approach theory when determining the impact of economic growth and health on social welfare provides an intuitively correct measure.
\end{abstract}

JEL Code: I31.

Matthew Clarke
Centre for Strategic Economic Studies
Victoria University
PO Box 14428
Melbourne City MC
Victoria8001
Australia
matthew.clarke@vu.edu.au

The authors wish to thank Dr P. Lawn for assistance with the adjustments made for Australia and Dr A. Israngakurn for his assistance with adjustments for Thailand. The authors also wish to acknowledge the Australian Research Council (grant LP0348013) and the Merck Company Foundation for the financial assistance provided undertaking this research.

Sardar M. N. Islam
Centre for Strategic Economic Studies
Victoria University
PO Box 14428
Melbourne City MC
Victoria 8001
Australia
sardar.islam@vu.edu.au

Sardar M. N. Islam

Victoria University

lbourne City $M C$

ictoria 8001

ardar.islam@vu.edu.au 


\section{INTRODUCTION}

Welfare economic analysis of health issues and policies can provide well balanced orderings of the states of the economy (see Islam and Mak 2000; Broome 1999). This paper provides an innovative framework for welfare economic analysis of the relationships between economic growth, health outcomes and social welfare for both a developing and developed country, which is lacking in the current literature. Economic growth can increase health outcomes and social welfare but its influence is limited by biological laws. Further, achieving economic growth may have negative externalities which reduce health outcomes (particularly when biological health limits are reached). A new health adjusted GDP indicator to investigate the relationship between economic growth, health outcomes and social welfare in both a developing (Thailand) and developed (Australia) country using social choice perspectives is developed within this paper.

The importance of good health is crucial when determining social welfare. Various health-based social welfare indices have been developed, such as life expectancy, expected disability-free life expectancy or healthy-life expectancy. Others include mortality rates, immunization rates, calories intake or height (see Bowling 1997 for a review). The major limitations of these indicators is that they can fail to adequately consider social welfare issues in evaluating alternative states of health outcomes, such as equity, efficiency, justice, social preferences for alternative states of the economy, costs and benefits of economic activities, policies and institutions and social time preferences.

Adjustments are made to gross domestic product (GDP) to reflect the relationships between economic growth, health outcomes and social welfare. These adjustments are estimated using normative social choice theory. Normative social choice theory allows optimal health outcomes to be fully considered in terms of equity, efficiency and other non-economic elements of social welfare when determining the impact of economic growth on social welfare. Social choice theory incorporates the various "social concerns" that are not adequately captured using individual preference satisfaction techniques 
within the market place and based on the possibility theorem (Sen 1970, 1999), as opposed to the impossibility theorem (Arrow 1951).

This paper analyses the social welfare impacts of health outcomes resulting from economic growth using Thailand and Australia as case studies, for 1975 to 1999, by applying a social choice approach based on cost-benefit analysis and systems analysis. (Data limitations exclude accurate calculation of adjustments over a longer time period). Two health adjusted gross domestic product (HAGDP) indices are prepared in this paper by adjusting GDP to reflect the social welfare impacts of achieving economic growth on health outcomes. This paper shows that differences exist between the relationships of economic growth, health outcomes and social welfare between developing and developed countries - economic growth has limited health outcome benefits at certain stage of a countries development, yet is very important at other times. This suggests that utilising the social choice approach theory when determining the impact of economic growth and health on social welfare provides an intuitively correct measure. While operationalisation of social choice theory in other areas of economics has been demonstrated (see Islam 1998 and 2001), the present paper shows such an exercise at an aggregate level of the GDP measure of social welfare is possible.

The innovative approach described in this paper should be considered as a work-inprogress. However, it does provide intuitively correct results which suggests further work should be invested in this approach (especially in standardising the methodology of estimating the health adjustments to GDP based on social choices).

The paper is structured as follows. This section introduced the paper. Section Two briefly reviews the traditional methods of measuring social welfare before its limitations are discussed. Section Three discusses the general relationship between economic growth, health outcomes and social welfare. Section Four introduces the concept of social choice theory before the theoretical HAGDP index based on the social choice approach is introduced in Section Five. This index is then empirically introduced in Section Six for 
both Australia and Thailand and the results are discussed and compared in Section Seven. Section Eight concludes this paper.

\section{GDP AS A MEASURE OF SOCIAL WELFARE}

One of several approaches to estimate social welfare is the use of GDP derived from standard national accounts. From its inception, GDP has been used as a measure of social welfare (McLean 1987). Economic growth is the measure of change in GDP between time periods. As such, it is now widely considered that economic growth is the measure of change in social welfare (Beckerman 1974, 1992, 1994; Dodds 1997; Drake and Nieuwenhuysen 1990; Eltis 1966; Hoselutz 1960; Manning and de Jonge 1996; Moss 1968; Thirlwell 1999).

There are legitimate reasons why GDP and other aggregate standard national account statistics, such as national income, are used as a measure of social welfare (Hicks 1940; Pigou 1920). These aggregate statistics measure what is produced within the economy and therefore are a measure of economic activity. They include activities such as food production, textiles and manufacturing and diseconomies such as defense spending, the justice system and certain health expenditures. Clearly these aggregate statistics accurately measure economic activity, but the question remains; is this the same as measuring social welfare? If social welfare is delineated into two parts, economic and non-economic, there is an "unverified probability" that economic welfare is a barometer of the "index of total welfare" (Pigou 1920). Within this position therefore, aggregated economic activity increases, so too does social welfare.

When policy makers explicitly or implicitly accept the identification of economic welfare with the supply of goods and services, they effectively ignore the differences between economic and non-economic welfare and the fact that activities favourably affecting economic welfare may conceivably affect non-economic welfare unfavourably (Abramovitz 1961). Therefore whilst economic growth might increase economic welfare, it may reduce non-economic welfare. The cumulative effect on social welfare may be positive, negative or neutral (Islam et al. 2001), however this approach assumes it to be 
positive. Within this paper, the non-economic welfare effect of most interest is health outcomes.

GDP per capita as a measure of social welfare is limited in two major ways. Firstly, it faces the limitations inherent in its own construction, failing to fully considered nonmarket transactions, the real price of natural resources, the need for leisure, income distribution, etc. (Islam and Clarke 2000). Secondly, it is limited through the inherent faults of price indexes, such as problems with intertemporal comparisons, changing tastes and preferences, changing capacity to enjoy satisfaction, etc. (Islam and Clarke 2000; Jorgenson 1997).

Despite these distinct limitations, it is possible to use GDP as a basis for a health focussed social welfare measure if a social choice approach is considered and certain (health based) adjustments to GDP are made (Islam and Clarke 2002). Adjusting GDP to improve its use as a measure of social welfare is not new (Sametz 1968; Nordhaus and Tobin 1973; Daly and Cobb 1990).

\section{ECONOMIC GROWTH, HEALTH OUTCOMES AND SOCIAL WELFARE}

Economic growth can improve social welfare by improving health outcomes (see Jack 1999). Economic growth provides the resources for increased public and private expenditure on health services, diets, shelter and medical research that can improve health outcomes.

Due to biological limits on health, the impact of economic growth also has real limits. Significant health improvements are experienced when base health rates are low with the introduction of basic health services and improvements in diet (afforded through economic growth). As health rates begin to reach biological limits, it becomes increasingly difficult to improve health outcomes despite economic growth affording increased technology, etc (see Dowrick et al. 1994). At this level of development, 
economic growth may begin to negatively affect health as the environmental externalities (pollution) associated with increasing economic growth begin to impact on health outcomes. Further, new acquired affluence (particularly in developing countries) may lead to less healthy diets based on conspicuous consumption of fatty or high cholesterol foods, increased rates of smoking and alcohol use, etc., which all may reduce health outcomes - despite higher level of income (see Jack 1999).

The distribution of income is also important vis-à-vis the relationship between economic growth, health outcomes and social welfare. 'One's health depends primarily on one's own consumption of medical care, food, shelter, clothing, water sanitation, and so forth. Thus, when aggregate data are used to analyze the correlations between health and these factors, it is not surprising that the distribution of income also matters. This is not a normative argument for a more egalitarian distribution of income (which may well be a highly commendable objective in itself), but solely a realization that an individual's health status us unlikely to be strictly proportional (in some ill-defined sense) to income, and relatively small transfers to the poor from the rich... can be expected to improve overall health levels' (Jack 1999, p. 36). Anand and Ravallion (1993) show that life expectancy is higher for countries with more egalitarian income distributions.

At the same time, the relationship between economic growth and health outcomes is not one-way. As the labour force is still an important factor of production, improved health leads to higher levels of production, economic growth and social welfare (Nordhaus 1998; OECD 2001).

The relationship between economic growth, health outcomes and social welfare is empirically investigated in this paper using an aggregative GDP based measure of social welfare. The main purpose of the empirical application undertaken in this paper is to illustrate the theoretical framework, based on social choice theory, can be operationalised and deserves further attention and work. 


\section{SOCIAL CHOICE THEORY}

Social choice theory has a long history (see Sen 1999 for a survey). The difficulties in making a judgement on the state of social welfare have long been recognised (Borda 1781 - reprinted 1953; de Condorcet 1785). Bergson (1938) first suggested that social choices could be discussed within a social welfare function. Arrow (1951) formulated the difficulties and inconsistencies of doing so within his 'impossibility theorem'. An alternative theorem of possibility was developed by Sen (1966, 1970, 1973 and subsequently added to by others, see Hammond 1976).

Social choice theory can be extended as a normative concept in which value judgements on the elements of optimal social welfare are made and operationalised within policy or measures of social welfare. This paper is such an exercise in normative social choice theory.

Normative social choices can be estimated using expert opinion (or analyst), government formulated public policy, or specific interviews of individuals on social welfare outcomes. The methodology for each technique is well established (Islam 2001). Using one, or a combination of the above, it is possible to determine the social choice perspectives on various social welfare issues. That this emphasis be placed on achieving an optimal social outcome should not be considered unusual. 'Samuelson's (1956) consensus model of the household assumes that all members pool their resources and work in concert to maximise a common utility function' (Slesnick 2001, p. 32). Social choice extends this consensus from the household to the society.

The framework developed in the following sections will use social choice theory, predicated on the possibility theorem, to identify and estimate society's choices on various externalities of achieving economic growth on health outcomes and social welfare. Adjustments which reflect these externalities will be made to GDP in order to develop a new indicator of the relationships between economic growth, health outcomes and social welfare. 


\section{THE HEALTH ADJUSTED GDP (HAGDP) INDEX}

Health outcomes are crucial when determining social welfare. However, existing literature often does not specify this variable in an appropriate manner when measuring welfare and focuses rather on the issue of preparing social welfare measurements solely on the basis of an unadjusted Gross Domestic Product (GDP). Measures of GDP (or other standard national account measures) fail to adequately represent movements in health outcomes yet various studies have shown the correlation between GDP and health outcomes (see Jack 1999 for a review). The conventional approach to measuring social welfare (which includes health), assumes that social welfare is a positive function of economic growth.

This conventional approach also fails to incorporate both the positive and negative impacts upon health outcomes of attaining economic growth or the biological limits on health outcomes. It is possible to use a cost-benefit framework and systems analysis to estimate the total impact of economic growth on health quality outcomes. The resultant measure is an estimated measure of health quality since it does indicate the extent to which economic growth overstates its impact on health quality outcomes. This adjusted GDP measure provides data on health outcomes.

\subsection{The HAGDP approach}

The basis of this new approach to measuring health based social welfare is GDP. However, this approach is limited as it fails to explicitly consider the impact of health on social welfare (Clarke and Islam 2002). This limitation can be overcome though by specifying a social welfare function:

HAGDP $\quad=\quad$ GDP $-\mathbf{I}-\mathbf{W}-\mathbf{A}-\mathbf{L}$

where HAGDP

$=\quad$ health adjusted GDP

GDP

$=\quad$ gross domestic product

$=\quad$ adjustment made for income inequality 


$\begin{array}{lll}\mathrm{W} & = & \text { adjustment made for water pollution } \\ \mathrm{A} & = & \text { adjustment made for air pollution } \\ \mathrm{L} & = & \begin{array}{l}\text { adjustment made for long-term environmental } \\ \text { damage }\end{array}\end{array}$

Within this paper, four health quality adjustments, based on the social choice approach (expert opinion) will be made to Thailand and Australia's GDP over the period of twenty years, from 1975 to $1995(\mathrm{t})$. These adjustments are income inequality, water pollution, air pollution, and long-term environmental damage. It is assumed that the benefits to health outcomes, from economic growth, are captured within GDP (see Nordhaus 1998 for an estimate of this). The estimation of the negative adjustments are based on common approaches found within the Index of Sustainable Economic Welfare (ISEW) literature (see Daly and Cobb 1990; Cobb and Cobb 1994; Cobb et al. 1995). It should be noted that due to data limitations, the approaches for estimating water and air pollution and long-term environmental damage is different for Australia and Thailand. However, it is felt that these different methodologies do not undermine the analysis that follows. Further work is required however to standardise the methodologies used between countries. The full calculation of these adjustments can be found in Clarke and Islam (2003) and Lawn (2001).

Each of these adjustments are made as they reflect an externality of achieving economic growth on health outcomes and hence social welfare. Within the present paper, the adjustments being made to GDP are unweighted. Further work on issues of weighting is required.

The adjustments made to GDP in this manner result in a new measure that represents both the stock and flow of a society's health outcomes.

By using GDP as a measure of social welfare a unrealistic impression is given. Such a index increases over three times within this twenty-five year period. Such an improvement in health quality seems unlikely. Therefore, certain adjustments that 
consider the positive and negative impacts of health quality caused by this economic growth will provide a better and intuitively correct measure of health quality social welfare.

\section{EMPIRICAL APPLICATION TO THAILAND AND AUSTRALIA}

Within this empirical application, as stated previously, the health outcome benefits of economic growth are considered to be implicitly contained in GDP as aggregate revealed preferences contain the additional expenditure on health services by both private and public sectors.

\subsection{Income Distribution}

Income levels are correlated with health quality outcomes (Jack 1999; Williams and Cookson 2000; Clayton and Radcliffe 1996). Yet, standard national accounts, such as GDP, do not consider income distribution. If income levels are correlated to health, unequal income distribution will lead to unequal health quality distributions. Therefore, the first adjustment within this new approach is to consider the distribution of income within Thailand (Appendix 1) and Australia (Appendix 2). The divergence between optimal market outcomes and optimal social outcomes begins within the issue of equity. Equity is important in increasing social welfare (Sen 1973), and in particular health (Anand and Ravllion 1993). When considering society's choices, preferences and value judgements on income inequality, the State has an essential prerogative to redistribute income (Musgrave 1959; Stoleru 1975). Within this health-based indicator, the social choice perspective on equity is imbedded in this analysis.

To estimate the social choice adjustment for income inequality on health outcomes, GDP is weighted by an index of distributional inequality based on assigning a value of 100.0 in the first year and adjusted accordingly to changes in the Gini co-efficient for the following years. 
Over the period of analysis, the cost of growing income inequality in Thailand has been nearly 20 percent. Within Australia, this figure is greater, over 30 percent. The impact of income inequality of this new health-based social welfare measures is that increasingly inequality reduces the positive impact of economic growth on health outcomes.

Figure 1 Comparison of Income adjusted for Inequality for Thailand, 1975-1999 (1988 prices in millions of baht)

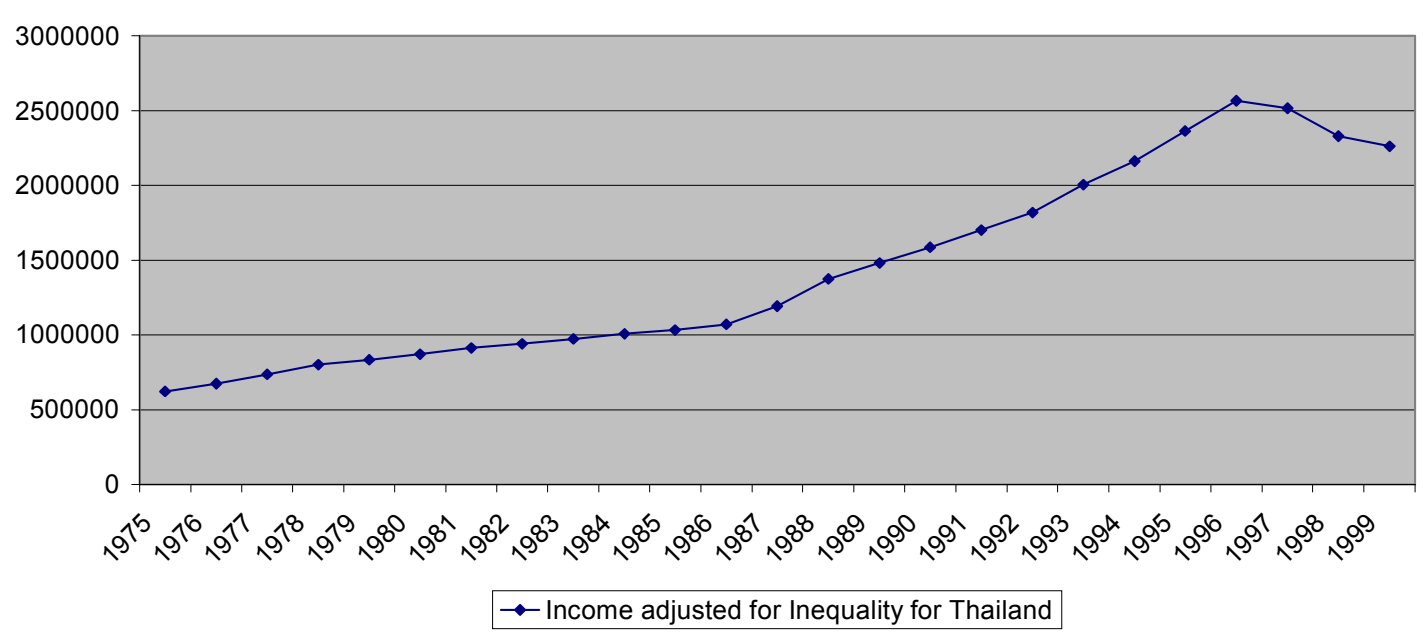

Figure 2 Comparison of Income adjusted for Inequality for Australia, 1975-1999 (1988 prices in millions of AUD)

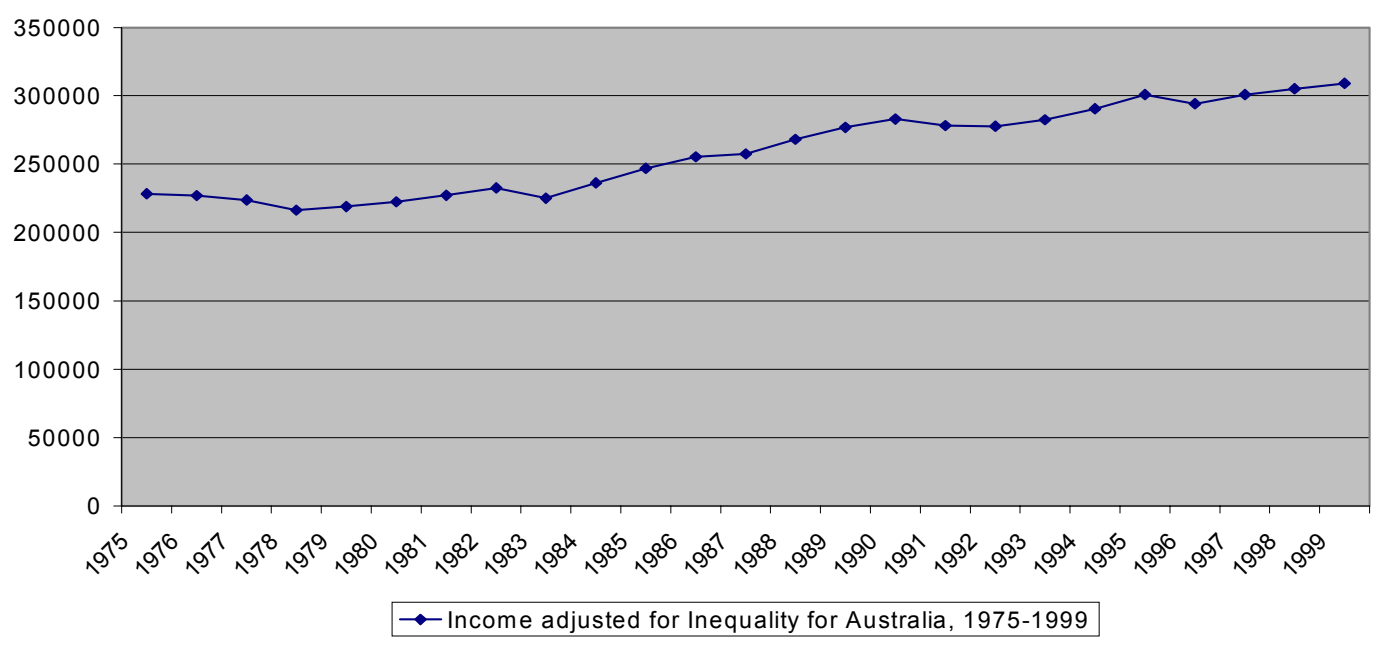




\subsection{Water Pollution}

Economic growth can place pressure on water resources through the dumping of wastes in rivers, decreasing water levels through inappropriate development (such as golf courses in developing countries) or the increase in salinity through over use of land. Water is necessary for the survival of all, therefore water pollution of whatever kind can negatively impact well-being. As with air pollution, water pollution is not generally considered in the market prices of those goods and services that cause this pollution. This results in over supply and over demand at artificially low prices. A social choice perspective is able to provide an indicative value of these externalities and include the negative impact when calculating a social welfare index.

Figure $3 \quad$ Adjustment for Water Pollution in Australia, 1975-1999 (1988 prices in millions of AUD)

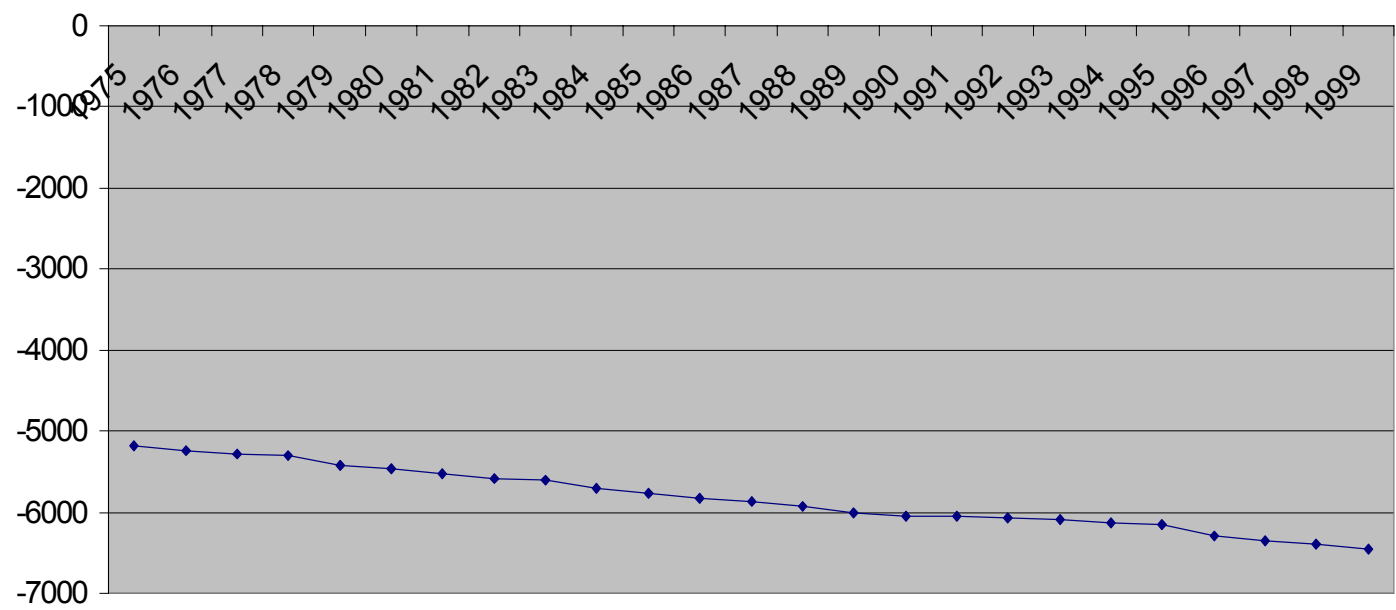

Adjustment for Water Pollution in Australia, 1975-1999

The social choice adjustment for water pollution in Australia is based on an initial value of water pollution damage using a ABS (1992) estimate and extrapolated forwards and backwards according to changes to economic growth. Within Thailand, the adjustment was calculated using the cost of abatement for water pollution as previously estimated 
(DIW 1986) and extrapolated forwards and backwards according to changes in economic growth based on an initial survey by Phansawas et al. (1987) and TESCO (1993).

Within Thailand, the estimated (and representative health cost) of water pollution has increased four times compared to an increase in Australia of only 25 percent.

Figure 4 Adjustment for Water Pollution in Thailand, 1975-1999 (1988 prices in millions of baht)

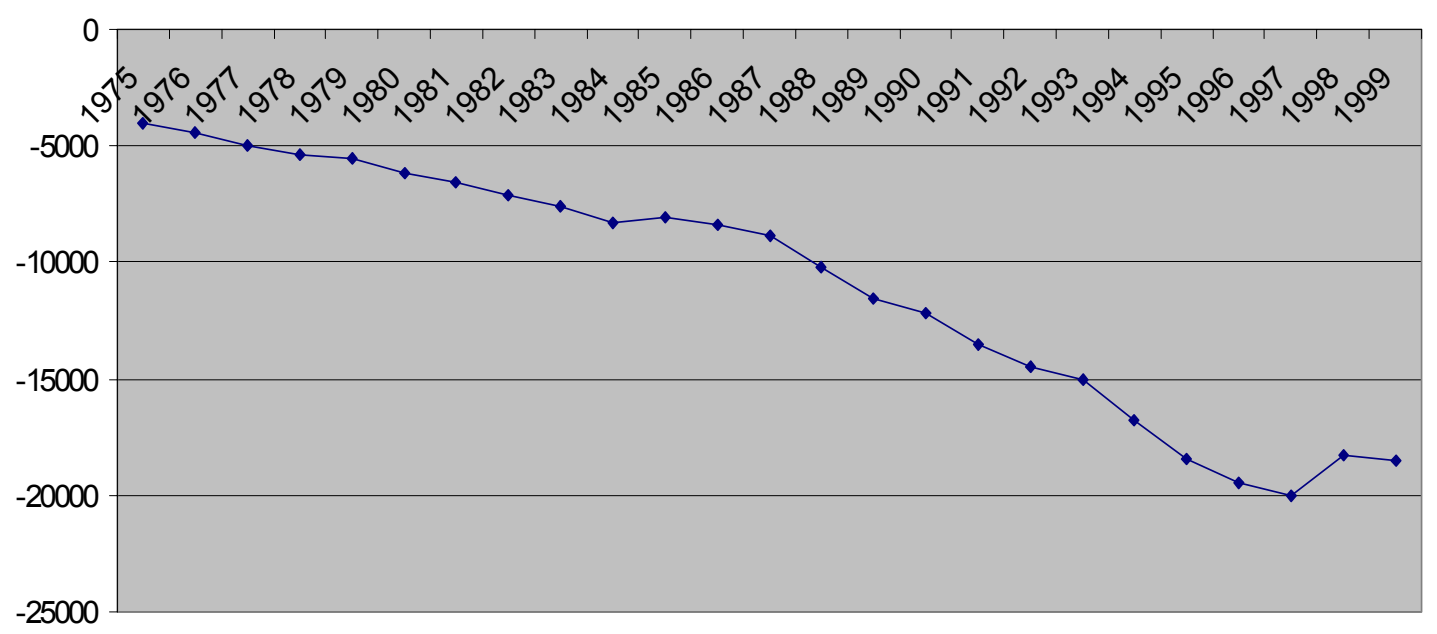

Adjustment for Water Pollution in Thailand, 1975-1999

\subsection{Air Pollution}

Air pollution occurs due to emission of pollutants into the atmosphere. Prior to industrialisation, the major pollutant was suspended particulate matters caused by fire (i.e. smoke). However, the atmosphere quickly absorbed this pollution with little cost to humans. However, since industrialisation and urbanisation, the level, mix and concentration of pollutants has substantially risen and changed and is no longer quickly and completely absorbed by the atmosphere. The result is poor air quality and the subsequent health and loss of amenity consequences of this. There are no market prices for air pollution as air is considered a free public good, even though air pollution negatively affects social welfare levels. Air pollution is an externality excluded from 
market prices. A social choice perspective must include the value of air pollution as a negative impact when calculating a social welfare index. Clean air adds to social welfare.

For Australia, the social choice adjustment for air pollution was calculated by using an initial value of air pollution damage was based on Daly and Cobb's (1990) estimate and extrapolated forwards and backwards according to changes to economic growth. In Thailand, the adjustment was based on the Cost of abatement for air pollution estimated using Guenno and Tiezzo (1990) and extrapolated forwards and backwards according to changes in economic growth based on an initial survey by DEDP (1990).

Economic growth in Thailand has increased the cost of air pollution dramatically in Thailand over the last twenty-five years, from 4117 million baht to 34056 million baht, in 1988 prices. Whereas, the cost of air pollution in Australia has remained constant despite increases in economic growth. This can be primarily be attributed to the relatively strong implementation of environmental regulations in Australia over the past twenty-five years and the poor implementation of government regulations within Thailand (Poungsomlee and Ross 1992).

Figure 5

Adjustment for Air Pollution in Thailand, 1975-1999 (1988 prices in millions of baht)

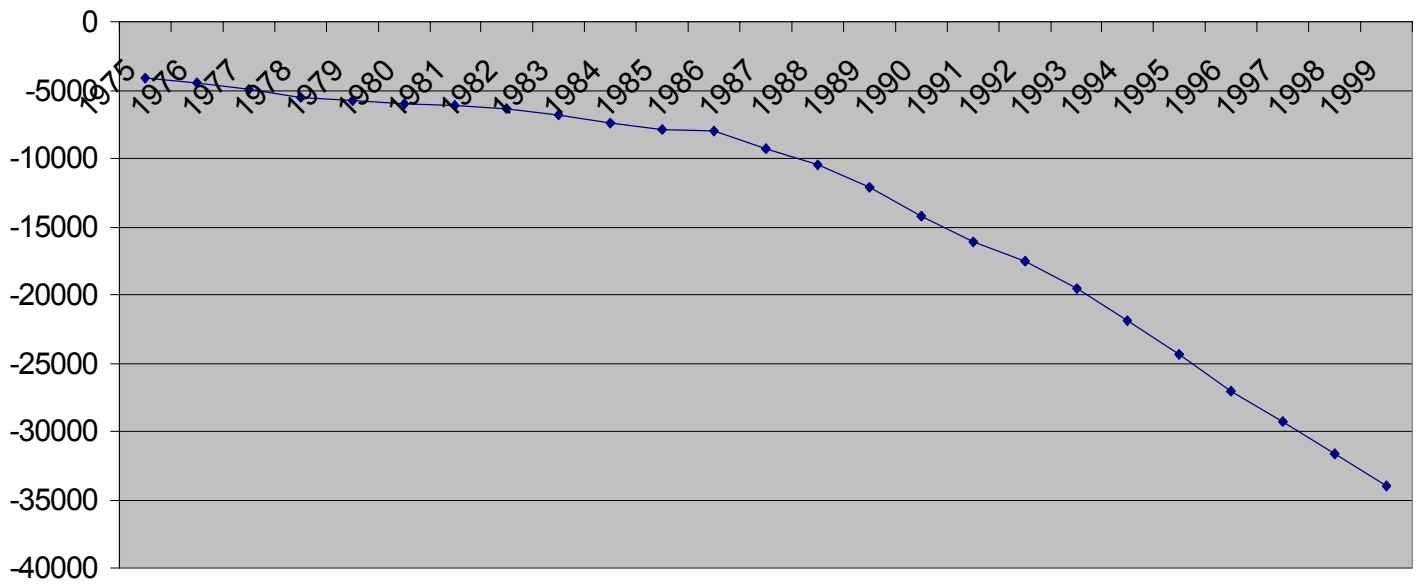

Adjustments for Air Pollution in Thailand, 1975-1999 


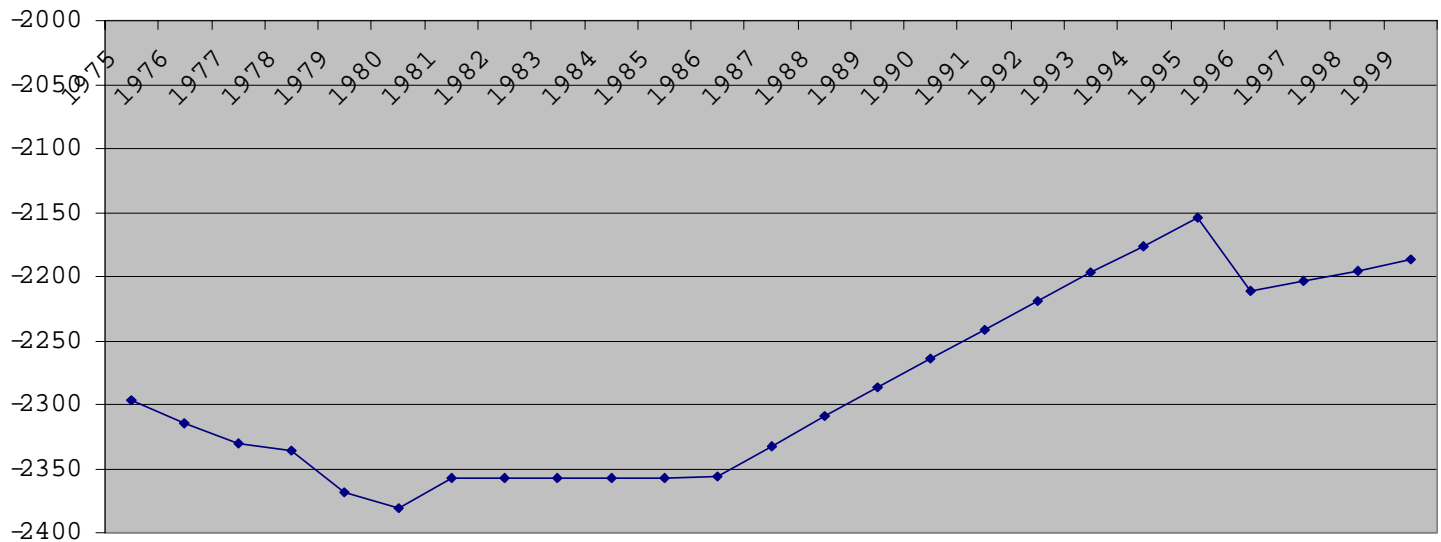

A d justm ents forA irP ollution, 1975-1999

\subsection{Long-term Environmental Damage (and Health Implications)}

Whilst Beckerman (1995) argues that pollution will decline at a certain point when sufficient growth will afford the citizens of that economy to buy a cleaner environment, Ayres (1996) argues that the environment is the basis of all life and any damage is detrimental to well-being. Without a sustainable environment life on earth cannot exist. Externalities of environmental damage are not captured by market or individual preferences. However, expert opinion (Nordhaus 1991; Islam 2001, IPCC 2001a, 2001b) indicates that there are important costs to current and future social welfare caused by greenhouse emissions.

In Australia, annual consumption of energy for Australia was converted to crude oil barrels and multiplied by $\$ 2.50$ per barrel (see Daly and Cobb 1990) to estimate the amount that needs to be set aside for compensating future generations for long-term environmental damage. In Thailand, damages caused by greenhouse gas emissions, based on Nordhaus (1991), are extrapolated forwards and backwards according to changes in economic growth based on initial surveys of the RFS (various issues), MoA (1992) and DEDP (1990). 
Given the increase in carbon dioxide, nitrogen dioxide, chlorofluorocarbons (CFCs) and methane in the atmosphere through industrial activities brought about by increases in economic growth, the irreversible damage is great. Increased instances of skin cancer, high incidences of flooding and unpredictable weather will result.

Figure 7 Adjustments for Long-term Environmental Damage for Australia, 19751999 (1988 prices in millions of AUD)

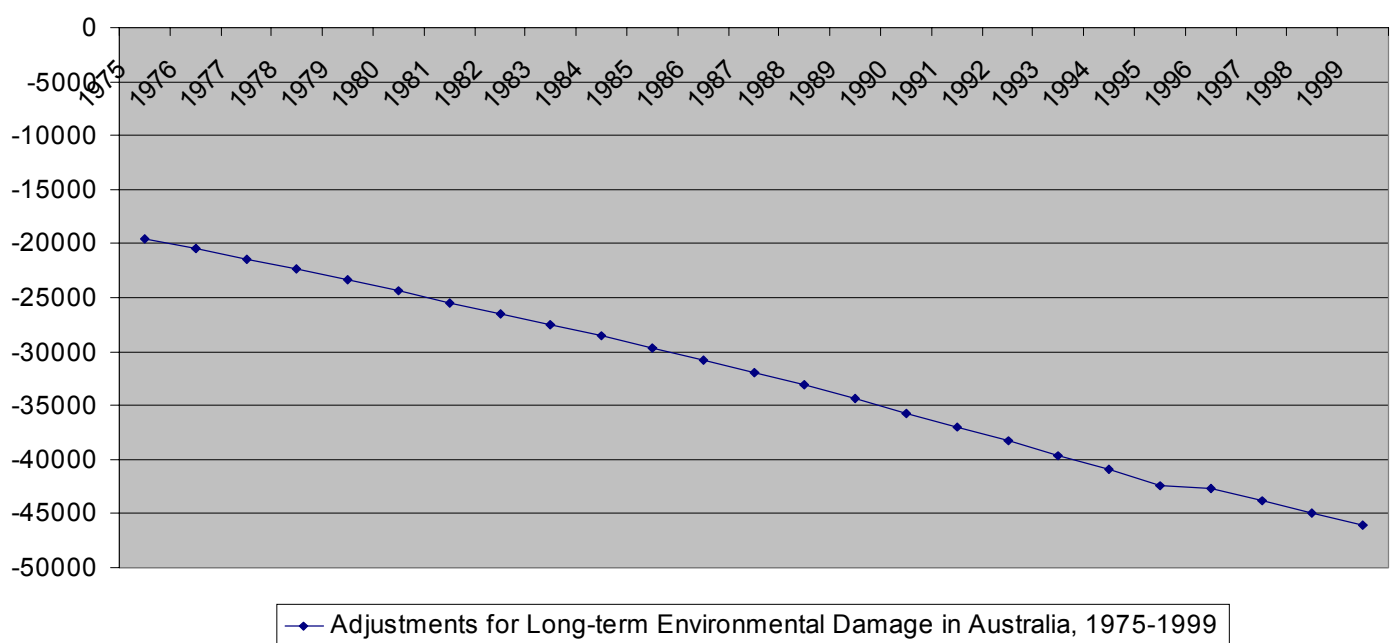

Figure 8 Adjustments for Long-term Environmental Damage for Thailand, 19751999 (1988 prices in millions of baht)

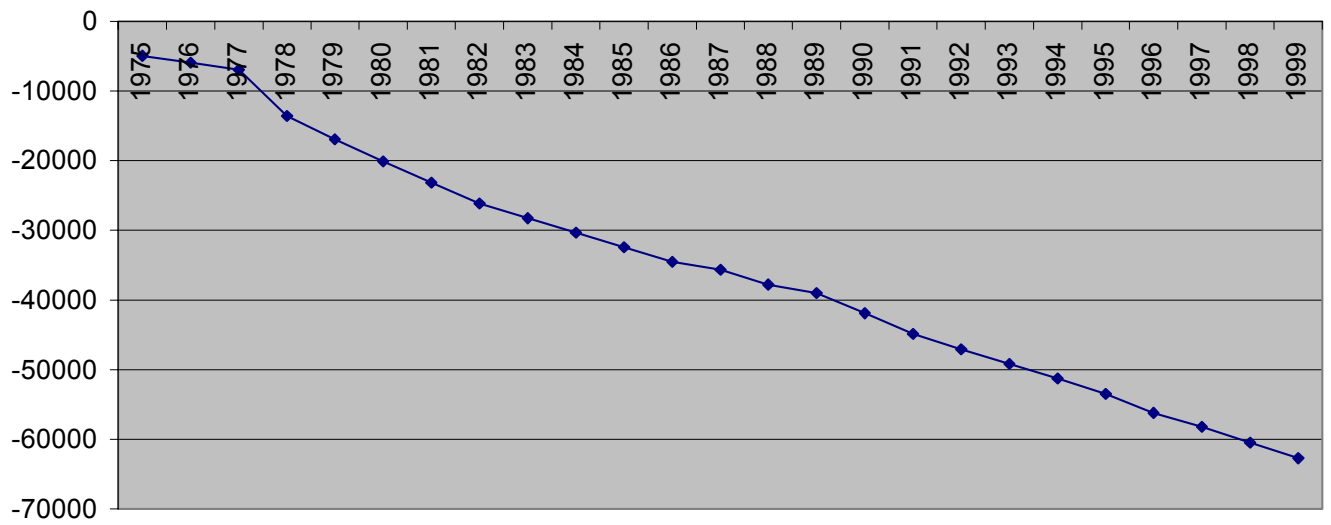

Adjustments for Long-term Environmental Damage, 1975-1999 


\subsection{Other Adjustments}

Other health based adjustments resulting from the process of achieving economic growth might also be considered, including cost of un/underemployment (stress), cost of junk food (obesity, heart disease), cost of tobacco sales (cancer), cost of commuting / urbanisation (stress), etc. Consideration of adjusting GDP to include the benefits of economic growth, such as increased life expectancy, is worthy of future work (Nordhaus 1998), but not without controversy (Lichtenberg 2003)

\section{RESULTS}

\subsection{Thailand}

There are three distinct periods of economic growth within Thailand over the last twentyfive years. The first period, 1975 to 1987 is a period of reasonable and steady growth. The second period, 1988 to 1997 is a period of accelerated growth, which finishes dramatically in 1997 due to the financial crisis of this time. The final period is the fallout of this crisis and shows GDP falling before showing signs of recovery in 1999.

The HAGDP tracks this path very closely over the last twenty-five years. This result suggests that the impact of economic growth on health outcomes, and hence social welfare, is quite beneficial. This result is intuitively correct. Despite the increasing income distribution, increasing pollution and long-term environmental damage, health outcomes continue to increase in line with economic growth. 
Figure 9 GDP per capita and HAGDO per capita for Thailand, 1975-1999 (1988 prices in baht)

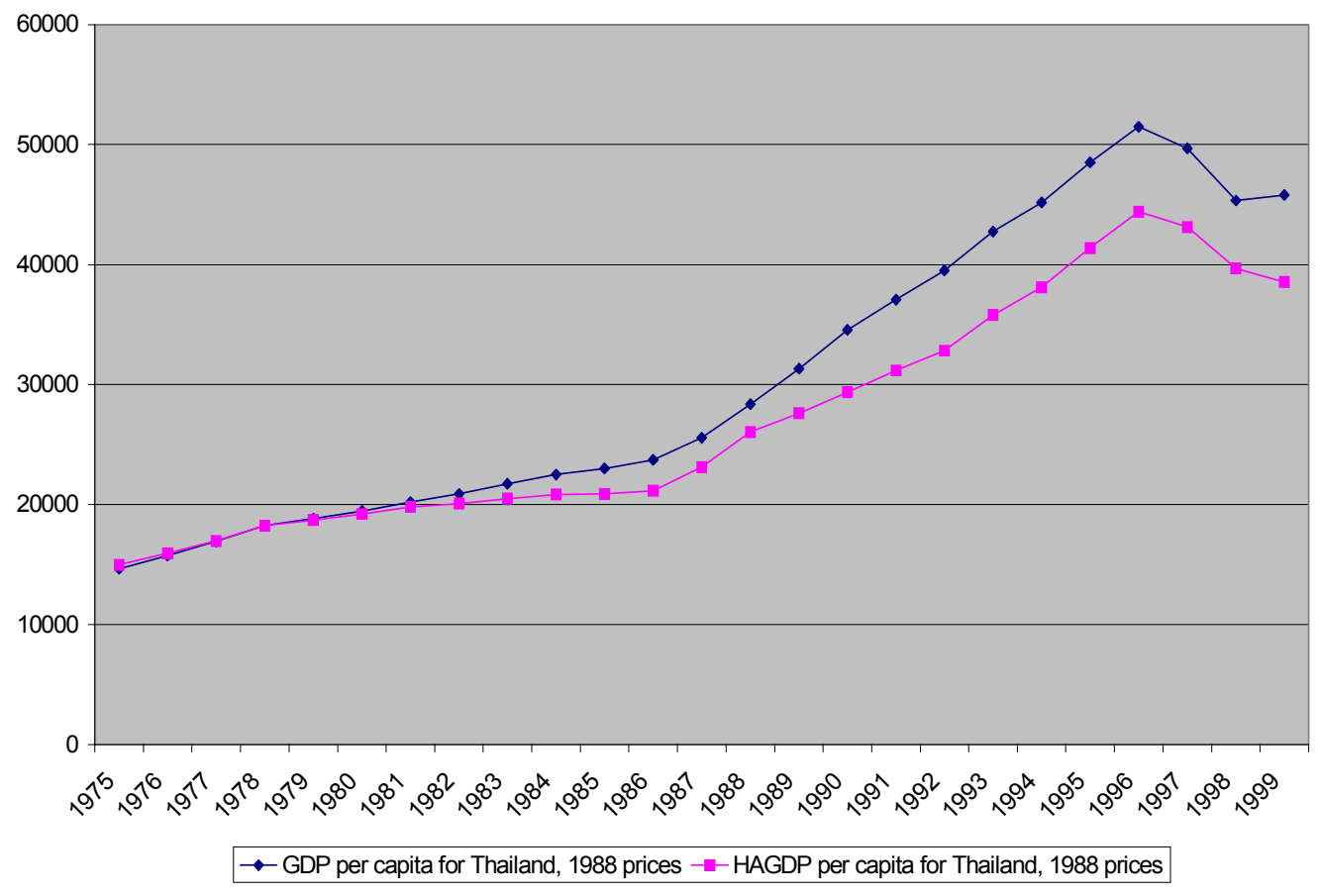


Table 1

Calculation of HAGDP per capita for Thailand, 1975-1999 (1988 prices in baht)

\begin{tabular}{|c|c|c|c|c|c|c|c|c|}
\hline Year & GDP & $\begin{array}{l}\text { Inequality } \\
\text { Adjustment }\end{array}$ & $\begin{array}{l}\text { Water } \\
\text { Pollution }\end{array}$ & Air Pollution & $\begin{array}{c}\text { Long-term } \\
\text { Environmental } \\
\text { Damage }\end{array}$ & Population & GDP per capita & $\begin{array}{l}\text { HAGDP per } \\
\text { capita }\end{array}$ \\
\hline 1975 & 621555 & 621555 & -4067 & -4117 & -4960 & 42391454 & 14662 & 14972 \\
\hline 1977 & 750054 & 735131 & -4956 & -4913 & -6932 & 44272639 & 16941 & 16984 \\
\hline 1978 & 824706 & 800375 & -5362 & -5516 & -13575 & 45221625 & 18236 & 18240 \\
\hline 1979 & 867797 & 833939 & -5503 & -5759 & -16893 & 46113756 & 18818 & 18695 \\
\hline 1980 & 913768 & 869676 & -6143 & -6046 & -20087 & 46961338 & 19457 & 19206 \\
\hline 1981 & 967374 & 911843 & -6584 & -6069 & -23175 & 47875002 & 20206 & 19795 \\
\hline 1982 & 1020084 & 941210 & -7151 & -6302 & -26170 & 48846927 & 20883 & 20080 \\
\hline 1983 & 1075922 & 972101 & -7583 & -6774 & -28255 & 49515074 & 21729 & 20493 \\
\hline 1984 & 1138329 & 1007639 & -8336 & -7382 & -30344 & 50583105 & 22504 & 20831 \\
\hline 1985 & 1191089 & 1033304 & -8033 & -7930 & -32428 & 51795651 & 22995 & 20884 \\
\hline 1986 & 1256538 & 1068848 & -8365 & -8030 & -34498 & 52969204 & 23722 & 22040 \\
\hline 1987 & 1377026 & 1191509 & -8833 & -9299 & -35653 & 53873172 & 25560 & 24075 \\
\hline 1988 & 1559804 & 1373309 & -10213 & -10508 & -37762 & 54960917 & 28380 & 26051 \\
\hline 1990 & 1946119 & 1585820 & -12145 & -14244 & -41914 & 56303273 & 34564 & 29379 \\
\hline 1991 & 2111740 & 1701369 & -13528 & -16144 & -44848 & 56961030 & 37073 & 31177 \\
\hline 1992 & 2282995 & 1818685 & -14443 & -17521 & -47047 & 57788965 & 39505 & 32838 \\
\hline 1993 & 2494748 & 2004296 & -15060 & -19479 & -49194 & 58336072 & 42765 & 35793 \\
\hline 1994 & 2669573 & 2162998 & -16733 & -21880 & -51269 & 59095419 & 45173 & 38123 \\
\hline 1995 & 2884495 & 2364146 & -18422 & -24307 & -53460 & 59460382 & 48511 & 41378 \\
\hline 1996 & 3095336 & 2566401 & -19493 & -27105 & -56206 & 60116182 & 51489 & 44401 \\
\hline 1997 & 3022012 & 2515409 & -20033 & -29257 & -58210 & 60816227 & 49690 & 43128 \\
\hline 1998 & 2787395 & 2329235 & -18296 & -31657 & -60469 & 61466178 & 45348 & 39691 \\
\hline 1999 & 2823416 & 2261990 & -18533 & -34056 & -62727 & 61661701 & 45788 & 38554 \\
\hline
\end{tabular}


Economic growth provides the basis for increased private and public expenditure on health services (Clarke and Islam 2003). Within developing countries, with lower health levels, incremental improvements in health services, diet, shelter, etc. can have significant net benefits for health outcomes. Traditional health statistics of life expectancy, infant mortality reflect these improvements in health outcomes in Thailand over the last twenty-five years (NSO 1999).

In regards to its relationships with health outcomes and social welfare, economic growth can be considered desirable in Thailand. While certain health costs associated with achieving economic growth exist, its net benefits are greater resulting in a constantly increasing HAGDP measure. This finding is intuitively correct.

\subsection{Australia}

A very different result is found for Australia. The HAGDP per capita index remains fairly stagnant over the twenty-five year period despite a constant increase in GDP per capita during the same time. Indeed, the HAGDP shows a number of small decreases in social welfare during this period of strong growth.

This result suggests that for developed countries, such as Australia, the benefits of economic growth on health outcomes is not strong as health levels are already high (cf. Dowrick et al. 1994). Unlike Thailand, it is not possible to make dramatic improvements in health outcomes, such as life expectancy or infant mortality rates, as these are already approaching their limit. 
Figure 10. GDP per capita and HAGDP per capita for Australia, 1975-1999 (1988 prices in AUD)

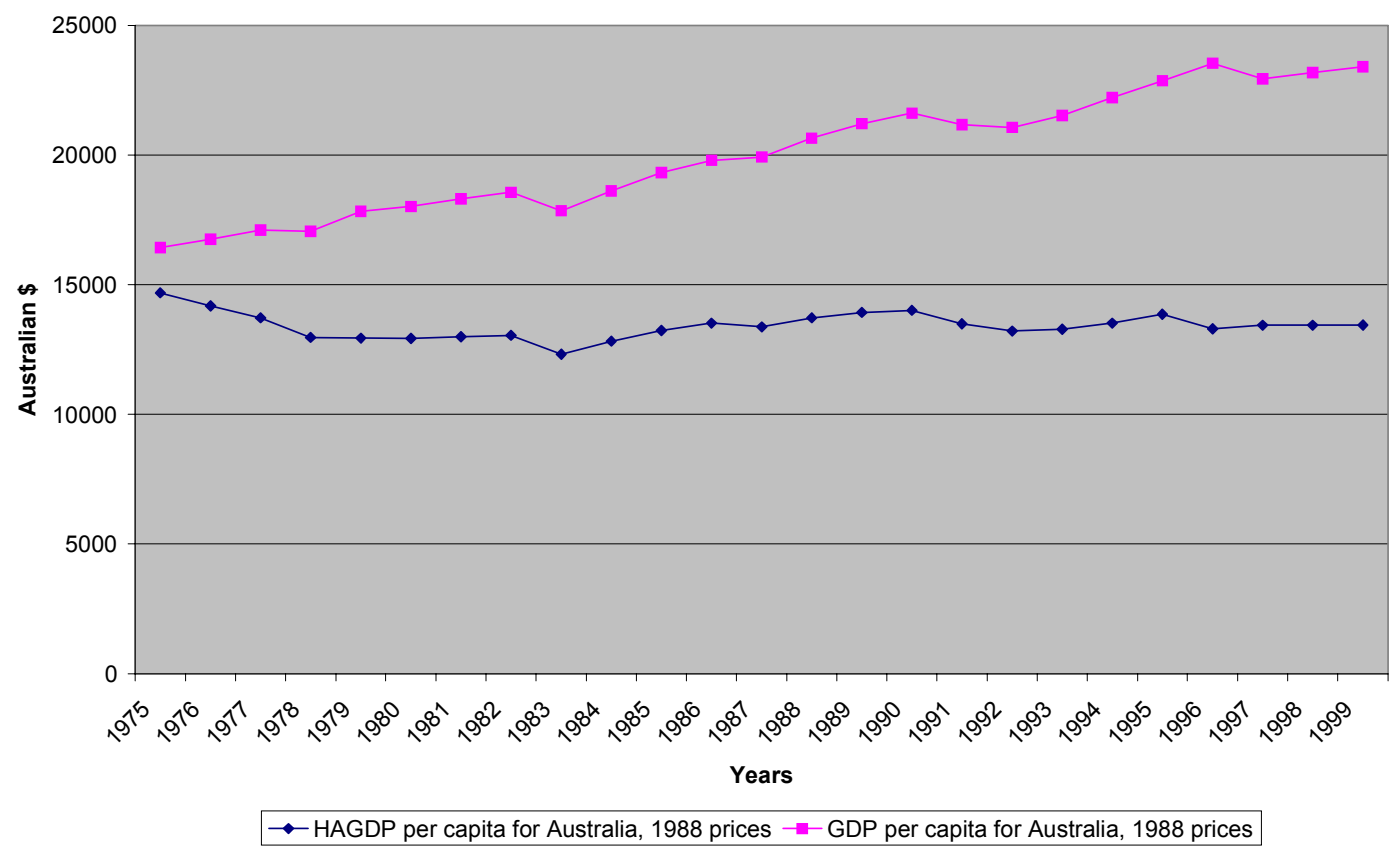

The desirability of economic growth in terms of its relationship between health outcomes and social welfare can be questioned in Australia. The net benefits of economic growth can be seen to be minimal and, at time, negative. Such an experience of economic growth can be termed health-stunting economic growth. This phenomena is so-called because this economic growth has checked the progress of health-based social welfare. During periods of health stunting economic growth, social welfare improves at decreasing rates, remains stagnant, and at times falls. Health stunting economic growth is undesirable as its effects are sub-optimal. 
Table 2

Calculation of HAGDP per capita for Australia, 1975-1999 (1988 prices in AUD)

\begin{tabular}{|c|c|c|c|c|c|c|c|c|}
\hline Year & GDP & $\begin{array}{c}\text { Inequality } \\
\text { Adjustment }\end{array}$ & $\begin{array}{c}\text { Water } \\
\text { Pollution }\end{array}$ & $\begin{array}{c}\text { Air } \\
\text { Pollution }\end{array}$ & $\begin{array}{c}\text { Long-term } \\
\text { Environmental } \\
\text { Damage }\end{array}$ & Population & GDP per capita & $\begin{array}{l}\text { HAGDP per } \\
\text { capita }\end{array}$ \\
\hline 1975 & 228330 & 228330 & -5172 & -2297 & -19592 & 13893000 & 16435 & 14487 \\
\hline 1976 & 235190 & 227018 & -5232 & -2315 & -20484 & 14033000 & 16760 & 14180 \\
\hline 1977 & 242780 & 223761 & -5288 & -2330 & -21434 & 14192000 & 17107 & 13720 \\
\hline 1978 & 245015 & 216254 & -5308 & -2336 & -22409 & 14359000 & 17064 & 12968 \\
\hline 1979 & 258840 & 218985 & -5420 & -2369 & -23406 & 14516000 & 17831 & 12937 \\
\hline 1980 & 264775 & 222313 & -5456 & -2381 & -24429 & 14695000 & 18018 & 12933 \\
\hline 1981 & 273336 & 227212 & -5528 & -2357 & -25457 & 14923000 & 18316 & 12991 \\
\hline 1982 & 281935 & 232620 & -5580 & -2357 & -26515 & 15184000 & 18568 & 13051 \\
\hline 1983 & 274892 & 225137 & -5612 & -2357 & -27536 & 15394000 & 17857 & 12319 \\
\hline 1984 & 290031 & 236374 & -5696 & -2357 & -28588 & 15579000 & 18617 & 12821 \\
\hline 1985 & 305076 & 246825 & -5768 & -2357 & -29689 & 15788000 & 19323 & 13239 \\
\hline 1986 & 317123 & 255500 & -5820 & -2356 & -30801 & 16018000 & 19798 & 13517 \\
\hline 1987 & 324117 & 257644 & -5860 & -2333 & -31950 & 16264000 & 19928 & 13373 \\
\hline 1988 & 341487 & 268254 & -5932 & -2309 & -33134 & 16532000 & 20656 & 13724 \\
\hline 1989 & 356687 & 276930 & -6000 & -2287 & -34386 & 16814000 & 21214 & 13932 \\
\hline 1990 & 368814 & 283049 & -6048 & -2264 & -35675 & 17065000 & 21612 & 14009 \\
\hline 1991 & 366030 & 278349 & -6056 & -2242 & -36965 & 17284000 & 21177 & 13486 \\
\hline 1992 & 368415 & 277629 & -6060 & -2219 & -38273 & 17489000 & 21066 & 13213 \\
\hline 1993 & 380027 & 282459 & -6088 & -2197 & -39606 & 17656000 & 21524 & 13285 \\
\hline 1994 & 396385 & 290411 & -6124 & -2176 & -40970 & 17838000 & 22221 & 13518 \\
\hline 1995 & 412794 & 300832 & -6156 & -2154 & -42365 & 18054000 & 22864 & 13856 \\
\hline 1996 & 430270 & 294290 & -6294 & -2211 & -42642 & 18280000 & 23538 & 13301 \\
\hline 1997 & 424391 & 300879 & -6345 & -2203 & -43775 & 18498000 & 22943 & 13437 \\
\hline 1998 & 433776 & 305027 & -6397 & -2195 & -44909 & 18715000 & 23178 & 13440 \\
\hline 1999 & 443160 & 309176 & -6449 & -2186 & -46042 & 18933000 & 23407 & 13442 \\
\hline
\end{tabular}




\subsection{Summary Analysis}

Humans are bound by biological laws. Health outcomes are therefore limited. Despite constant economic growth, it should be expected that human health will begin to plateau at a certain stage. The HAGDP supports this view. During a period of development, economic growth can significantly improve health outcomes and hence social welfare, but at a certain point (coined the Threshold point (Max-Neef 1995) within a distinct, but related, context) economic growth produces diminishing health outcome returns. The results of this new indicator are not surprising, but do offer an entry point to a wider debate regarding the role economic growth plays in improving health outcomes and the limits to health improvements more generally.

Over the past twenty-five years average life expectancy has increased 12.2 years in Thailand (NSO 2001) but only 5.5 years in Australia (ABS 2001). It is not reasonable to expect average life expectancy to limitlessly increase. There are biological boundaries. Developed countries, such as Australia, may be approaching these natural limits and as a result economic growth loses its ability to significantly increase health based social welfare. In developing countries though, such as Thailand, low health levels mean that the impact of economic growth on health outcomes is still significant and the achievement of economic growth continues to be desirable in a health based social welfare sense.

This study demonstrates that the relationships between economic growth, health outcomes and social welfare is not fixed and is influenced by a countries development status. Economic growth generates both costs and benefits for health and health related social welfare. When countries have low base rates of health outcomes, the associated benefits of economic growth (improved diets, access to health care, basic medical treatment) outweigh the associated health costs (caused by pollution, environmental degradation, etc.) thus making economic growth desirable. However, at a certain point, (primarily determined by biological limits), the benefits of economic growth for health based social welfare reduce through the law of diminishing returns while the costs continue to increase. The result is health stunting economic growth in which healthbased social welfare is either stagnant or falling. 
Further work is required on the desirability of economic growth for health and concept of health-stunting economic growth more specifically.

\section{CONCLUSION}

This paper has developed a framework of welfare economic analysis using social choice theory to identify and estimate society's choices on those externalities affecting health outcomes caused through achieving economic growth. This paper has developed a new framework to study the relationships between economic growth, health outcomes and social welfare. This was achieved by measuring health based social welfare based on adjusting standard national account measures. By incorporating various aspects of welfare economics, cost-benefit analysis, systems analysis and social choice theory, it has been possible to adjust a conventional measure of social welfare to more fully consider health quality issues. Adjustments that reflect these externalities were made to GDP in order to develop a new indicator of the relationships between economic growth, health outcomes and social welfare. While the benefits can be considered to be included in the GDP account, explicit adjustments to GDP are required to consider these health outcome costs. GDP was adjusted so that it better reflects the empirical relationship between economic growth, health outcomes and social welfare. Unadjusted GDP is taken as a representative indicator of social welfare, which includes health and yet it may actually overstate health quality outcomes. A number of adjustments can take place that might make GDP a more accurate and intuitively correct measure of social welfare based on health outcomes.

The adjustments are based on the concept of social choice theory, in which social perspectives on social welfare impacts are considered rather than individual preferences revealed within the market place. Further work is required to standardise the methodologies used to calculate these adjustments to allow stronger comparisons between countries and stages of development. 
The empirical application of this approach to Thailand and Australia over a twenty-five year period found that economic growth has greater impact on health outcomes in developing countries than in developed countries. Such results are intuitively correct. As biological limits are approached, improvements in health increase at diminishing rates. Because the attainment of economic growth can have negative consequences for health, it is possible that the bet benefits of economic growth on health become either stagnant or , at times, negative. Such an outcome is termed health-stunting economic growth.

This new approach is important as it highlights the limitations of current convention measures of social welfare. Though this approach was applied to Thailand and Australia, it is generally applicable to measure health-based social welfare under any circumstances.

This paper remains a work in progress and additional work is required on the selection of adjustments, methodology and estimation, however it can be seen as an innovative approach worthy of continued investigation. 


\section{References}

Abramovitz, M. (1961), 'The Welfare Interpretation of Secular Trends in National Income and Product', in M. Abramovitz et al. (eds) The Allocation of Economic Resources, Stanford University Press, Stanford.

Anaud, S. and Ravallion, M. (1993), 'Human Development in Poor Countries: One the Role of Private Income and Public Services', Journal of Economic Perspectives, Vol. 7, No. 1, pp. 133-150.

Arrow, K. (1951), Social Choice and Individual Value, John Wiley \& Sons, New York.

Australian Bureau of Statistics (ABS) (1992), Cost of Environmental Protection, ABS, Canberra.

Australian Bureau of Statistics (ABS) (2001), Australia's National Statistics, ABS, Canberra.

Ayres, R. (1996), 'Limits to Growth Paradigm', Ecological Economics, Vol. 19.

Beckerman, W. (1974), In Defense of Economic Growth, Jonathan Cape, London.

Beckerman, W. (1992), 'Economic Growth and the Environment', World Development, Vol. 20, No. 4, pp. 481-496.

Beckerman, W. (1995), 'Is economic growth still desirable?', in W. Beckerman (ed), Growth, the Environment and the Distribution of Income, Edward Elgar, Aldershot.

Bergson, A. (1938), 'A Reformulation of Certain Aspects of Welfare Economics', Quarterly Journal of Economics, February.

Borda, J. (1780 - reprinted in 1953), 'Memoire sur les Elections au Scrutin', Histoire de L'Academic Royale des Sciences, translated by A. de Grazia, 'Mathematical Derivation of an Election System', Isis, Vol. 44, No. 1-2, pp. 42-51.

Bowling, A. (1997), Measuring Health, Open University Press, London.

Broome, J. (1999), Ethics out of Economics, Cambridge University Press, Cambridge.

Clayton, A. and Radcliffe, N. (1996), Sustainability: A Systems Approach, Earthscan Publications, London.

Clarke, M. and Islam, S. (2002), 'The Relationship between GDP and Health: A New Health Quality Adjusted GDP Measure for Social Welfare Empirically Applied too Thailand', paper presented at the Australian Health Economics Society, Sydney, 18-19 July.

Clarke, M. and Islam, S. (2003), Economic Growth and Social Welfare: The Operationalisation of Social Choice Theory, mimeo, Victoria University, Melbourne.

Condorcet, M. de. (1785), Essai sur l'Application de l'Analyse a la Probabilitie des Decisions Rendues a la Plualite des voix, L'Imprimerie Royal, Paris.

Cobb, C. and Cobb, J. (1994), The Green National Product, University Press of America, Lanham.

Cobb, C., Halstead, T. and Rowe, J.,(1995), The Genuine Progress Indicator, Redefining Progress, San Francisco.

Daly, H. and Cobb J. (1990), For the Common Good, Beacon Press, Boston.

Department of Energy Development and Promotion (DEDP) (1990), Industry Survey, DEDP, Bangkok (in Thai).

Department of Industrial Works (DIW) (1986), Industry Survey - 1985, DIW, Bangkok (in Thai).

Dodds, S. (1997), 'Economic Growth and Human Well-Being' in M. Diesendorf and C. Hamilton (eds), Human Ecology and Human Economy, Allen and Unwin, Sydney.

Dowrick, S., Dunlop, Y. and Quiggin, J. (1994), 'Living Standards and Social Welfare Indicators: A Revealed Preference Approach', CEPR Discussion Paper No. 312, CEPR, London.

Drake, P. and Nieuwenhuysen, T. (1988), Economic Growth for Australia, Oxford University Press, Melbourne.

Eltis, W. (1966), Economic Growth, Hutchinson and Co., London.

Guenno, G. and Tiezzi, S. (1998), 'The Index of Sustainable Economic Welfare (ISEW) for Italy', Nota Di Lavoro, No. 5.98

Hammond, P. (1976), 'Equity, Arrow's Conditions and Rawls' Difference Principles', Econometrica, Vol. 44, No. 4, pp. 793-804.

Hicks J. (1940), 'The Valuation of Social Income', Economica Vol. 7, pp. 104--24.

Hoselitz, B. (1960), Sociological Aspects of Economic Growth, The Free Press, New York.

Intergovernmental Panel on Climate Change (IPCC), (2001a), Climate Change 2001: Economic and Social Dimensions of Climate Change, Cambridge University Press, New York. 
Intergovernmental Panel on Climate Change (IPCC), (2001b), Climate Change 2001: Impact, Adaptations and Mitigation of Climate Change: Scientific-Technical Analysis, Cambridge University Press, New York.

Islam, S. (1998), Mathematical Economics of Multi-level Optimalisation, Springer-Verlag, Heidelberg.

Islam, S. (2001), Optimal Growth Economics, North Holland Publishing Co., Amsterdam.

Islam, S. and Clarke, M. (2000), Social Welfare and GDP: Can We Still Use GDP For Welfare Measurement?, seminar paper presented at the Centre for Strategic Economic Studies, Victoria University, 7 September.

Islam, S. and Clarke, M. (2002), The Relationship between Economic Development and Social Welfare', Social Indicators Research, Vol. 57, No. 3, pp. 201-228.

Islam, S. and Mak, C. (2000), Welfare Economics of Health Programs: Social CBA of the Pharmaceutical Benefits Scheme, seminar paper presented at CSES, Victoria University, Melbourne, 30 November.

Islam, S., Munasinghe, M. and Clarke, M. (forthcoming), 'Making Long-term Economic Growth More Sustainable: Evaluating the Costs and Benefits', Ecological Economics.

Jack, W. (1999), Principles of Health Economics for Developing Countries, The World Bank, Washington DC.

Jorgenson, D. (1997), Welfare, Vol. 2, The MIT Press, Cambridge, Ma.

Lawn, P. (2001), 'In Defence of the Strong Sustainability Approach to National Income Accounting', Environmental Taxation and Accounting, Vol. 3, No. 1, pp. 29-47.

Lichtenberg, F. (2003), 'Sources of US Longevity', paper presented at the CESIfo Conference on Health and Economic Policy, Munich, 27-28 June.

Manning, I. and De Jonge, A. (1996), 'The New Poverty: Causes and Responses' in P. Sheehan, B. Grewal, and M. Kumnick (eds), Dialogues on Australia's Future, Centre for Strategic Economic Studies, Melbourne.

Max-Neef, M. (1995), 'Economic Growth and Quality of Life: A Threshold Hypothesis', Ecological Economics, Vol. 15, No. 2, November, pp. 115-118.

McLean, I. (1987), 'Economic Wellbeing' in R. Madock and I. McLean (eds), The Australian Economy in the Long Run, Cambridge University Press, New York.

Ministry of Agriculture (MoA) (1992), Thailand's Agricultural Statistics 1991-1992, Department of Agriculture, Bangkok (in Thai).

Moss, M. (1968), 'Consumption: A Report on Contemporary Issues' in E. Sheldon and W. Moore (eds), Indicators of Social Change, Russell Sage Foundation, New York.

Musgrave, T. (1959), The Theory of Public Finance, MacGraw-Hill, New York.

National Statistical Office (NSO) (1999), Statistical Yearbook Thailand, 1998, No. 45, National Statistical Office, Bangkok.

National Statistical Office (NSO) (2001), Statistical Yearbook Thailand, 1999, No. 47, National Statistical Office, Bangkok.

Nordhaus, W. and Tobin, J. (1973), 'Is Growth Obsolete?,' in M. Moss (ed.) The Measurement of Economic and Social Planning, Economic Growth, National Bureau of Economic Research, New York.

Nordhaus, W. (1991), 'To Slow or Not to Slow: The Economics of the Greenhouse Effect', Economic Journal, Vol. 101, pp. 920-937.

Nordhaus, W. (1998), The Health of Nations: Irving Fisher and the Contribution of Improved Longevity to Living Standards, Cowles Foundation Discussion Paper No. 1200, Cowles Foundation for Research in Economics, New Haven.

Organisation for Economic Co-operation and Development (OECD) (2001), The Well-Being of Nations: The Role of Human and Social Capital, OECD, Paris.

Phansawas, T. et al. (1987), Community Wastewater Pollution in The Bangkok Metropolitan Area, ONED, Bangkok (in Thai).

Pigou, A. (1920), The Economics of Welfare, $1^{\text {st }}$ edn, Macmillian, London.

Poungsomlee, A. and Ross, H. (1992), Impacts of Modernisation and Urbanisation in Bangkok, Institute for Population and Social Research, Mahidol University, Bangkok.

Sametz, A. (1968), 'Production of Goods and Services: The Measurements of Economic Growth' in E. Sheldon and W. Moore (eds), Indicators of Social Change, Russell Sage Foundation, New York. 
Sen, A. (1966), 'A Possibility Theorem on Majority Decisions', Econometrica, No. 34.

Sen, A. (1970), Collective Choice and Social Welfare, North Holland Publishing Co., Amsterdam.

Sen, A. (1973), 'Behaviour and the Concept of Preference' Economica, Vol. 40, pp. 241-89.

Sen, A. (1977), 'Rational Fools: A Critique of the Behavioural Foundations of Economic Theory', Philosophy and Public Affairs, Vol. 6, pp. 317-44.

Sen, A. (1999), 'The Possibility of Social Choice' The American Economic Review, June, pp. 349-378.

Slesnick, D. (2001), Consumption and Social Welfare, Cambridge University Press, Cambridge.

Stoleru, L. (1975), Economic Equilibrium and Growth, North-Holland Publishing Company, Amsterdam.

TESCO (1993), Environment Plan for Development in Bangkok and Central Areas, presented to the Pollution Control Department, Ministry of Science, Technology and Environment, Bangkok (in Thai).

Thirlwell, A. (1999), Growth and Development, $6^{\text {th }}$ edn, MacMillan Press, London.

Williams, A. and Cookson, R. (2000), 'Equity in Health', in A. Culyer and J. Newhouse (Eds.), Handbook of Health Economics, Vol. 1B. North Holland-Elsevier, Amsterdam. 


\title{
CESifo Working Paper Series
}

\author{
(for full list see www.cesifo.de)
}

938 Sören Blomquist and Vidar Christiansen, Is there a Case for Public Provision of Private Goods if Preferences are Heterogeneous? An Example with Day Care, May 2003

939 Hendrik Jürges, Kerstin Schneider, and Felix Büchel, The Effect of Central Exit Examinations on Student Achievement: Quasi-experimental Evidence from TIMSS Germany, May 2003

940 Samuel Bentolila and Juan F. Jimeno, Spanish Unemployment: The End of the Wild Ride?, May 2003

941 Thorsten Bayindir-Upmann and Anke Gerber, The Kalai-Smorodinsky Solution in Labor-Market Negotiations, May 2003

942 Ronnie Schöb, Workfare and Trade Unions: Labor Market Repercussions of Welfare Reform, May 2003

943 Marko Köthenbürger, Tax Competition in a Fiscal Union with Decentralized Leadership, May 2003

944 Albert Banal-Estañol, Inés Macho-Stadler, and Jo Seldeslachts, Mergers, Investment Decisions and Internal Organisation, May 2003

945 Kaniska Dam and David Pérez-Castrillo, The Principal-Agent Matching Market, May 2003

946 Ronnie Schöb, The Double Dividend Hypothesis of Environmental Taxes: A Survey, May 2003

947 Erkki Koskela and Mikko Puhakka, Stabilizing Competitive Cycles with Distortionary Taxation, May 2003

948 Steffen Huck and Kai A. Konrad, Strategic Trade Policy and Merger Profitability, May 2003

949 Frederick van der Ploeg, Beyond the Dogma of the Fixed Book Price Agreement, May 2003

950 Thomas Eichner and Rüdiger Pethig, A Microfoundation of Predator-Prey Dynamics, May 2003

951 Burkhard Heer and Bernd Süssmuth, Cold Progression and its Effects on Income Distribution, May 2003 
952 Yu-Fu Chen and Michael Funke, Labour Demand in Germany: An Assessment of NonWage Labour Costs, May 2003

953 Hans Gersbach and Hans Haller, Competitive Markets, Collective Decisions and Group Formation, May 2003

954 Armin Falk, Urs Fischbacher, and Simon Gächter, Living in Two Neighborhoods Social Interactions in the LAB, May 2003

955 Margarita Katsimi, Training, Job Security and Incentive Wages, May 2003

956 Clemens Fuest, Bernd Huber, and Jack Mintz, Capital Mobility and Tax Competition: A Survey, May 2003

957 Edward Castronova, The Price of 'Man' and 'Woman': A Hedonic Pricing Model of Avatar Attributes in a Synthetic World, June 2003

958 Laura Bottazzi and Marco Da Rin, Financing Entrepreneurial Firms in Europe: Facts, Issues, and Research Agenda, June 2003

959 Bruno S. Frey and Matthias Benz, Being Independent is a Great Thing: Subjective Evaluations of Self-Employment and Hierarchy, June 2003

960 Aaron Tornell and Frank Westermann, Credit Market Imperfections in Middle Income Countries, June 2003

961 Hans-Werner Sinn and Wolfgang Ochel, Social Union, Convergence and Migration, June 2003

962 Michael P. Devereux, Measuring Taxes on Income from Capital, June 2003

963 Jakob de Haan, Jan-Egbert Sturm and Bjørn Volkerink, How to Measure the Tax Burden on Labour at the Macro-Level?, June 2003

964 Harry Grubert, The Tax Burden on Cross-Border Investment: Company Strategies and Country Responses, June 2003

965 Kirk A. Collins and James B. Davies, Measuring Effective Tax Rates on Human Capital: Methodology and an Application to Canada, June 2003

966 W. Steven Clark, Using Micro-Data to Assess Average Tax Rates, June 2003

967 Christopher Heady, The 'Taxing Wages' Approach to Measuring the Tax Burden on Labour, June 2003

968 Michael P. Devereux and Alexander Klemm, Measuring Taxes on Income from Capital: Evidence from the UK, June 2003

969 Bernhard Eckwert and Itzhak Zilcha, The Effect of Better Information on Income Inequality, June 2003 
970 Hartmut Egger and Josef Falkinger, The Role of Public Infrastructure for Firm Location and International Outsourcing, June 2003

971 Dag Morten Dalen and Trond E. Olsen, Regulatory Competition and Multi-national Banking, June 2003

972 Matthias Wrede, Tax Deductibility of Commuting Expenses and Residential Land Use with more than one Center, June 2003

973 Alessandro Cigno and Annalisa Luporini, Scholarships or Student Loans? Subsidizing Higher Education in the Presence of Moral Hazard, June 2003

974 Chang Woon Nam, Andrea Gebauer and Rüdiger Parsche, Is the Completion of EU Single Market Hindered by VAT Evasion?, June 2003

975 Michael Braulke and Giacomo Corneo, Capital Taxation May Survive in Open Economies, July 2003

976 Assar Lindbeck, An Essay on Welfare State Dynamics, July 2003

977 Henrik Jordahl and Luca Micheletto, Optimal Utilitarian Taxation and Horizontal Equity, July 2003

978 Martin D. D. Evans and Richard K. Lyons, Are Different-Currency Assets Imperfect Substitutes?, July 2003

979 Thorsten Bayindir-Upmann and Frank Stähler, Market Entry Regulation and International Competition, July 2003

980 Vivek Ghosal, Firm and Establishment Volatility: The Role of Sunk Costs, Profit Uncertainty and Technological Change, July 2003

981 Christopher A. Pissarides, Unemployment in Britain: A European Success Story, July 2003

982 Wolfgang Buchholz, Richard Cornes, and Wolfgang Peters, On the Frequency of Interior Cournot-Nash Equilibria in a Public Good Economy, July 2003

983 Syed M. Ahsan and Panagiotis Tsigaris, Choice of Tax Base Revisited: Cash Flow vs. Prepayment Approaches to Consumption Taxation, July 2003

984 Campbell Leith and Jim Malley, A Sectoral Analysis of Price-Setting Behavior in US Manufacturing Industries, July 2003

985 Hyun Park and Apostolis Philippopoulos, Choosing Club Membership under Tax Competition and Free Riding, July 2003

986 Federico Etro, Globalization and Political Geography, July 2003

987 Dan Ariely, Axel Ockenfels and Alvin E. Roth, An Experimental Analysis of Ending Rules in Internet Auctions, July 2003 
988 Paola Conconi and Carlo Perroni, Self-Enforcing International Agreements and Domestic Policy Credibility, July 2003

989 Charles B. Blankart and Christian Kirchner, The Deadlock of the EU Budget: An Economic Analysis of Ways In and Ways Out, July 2003

990 M. Hasham Pesaran and Allan Timmermann, Small Sample Properties of Forecasts from Autoregressive Models under Structural Breaks, July 2003

991 Hyun Park, Apostolis Philippopoulos and Vangelis Vassilatos, On the Optimal Size of Public Sector under Rent-Seeking competition from State Coffers, July 2003

992 Axel Ockenfels and Alvin E. Roth, Late and Multiple Bidding in Second Price Internet Auctions: Theory and Evidence Concerning Different Rules for Ending an Auction, July 2003

993 Pierre Salmon, The Assignment of Powers in an Open-ended European Union, July 2003

994 Louis N. Christofides and Chen Peng, Contract Duration and Indexation in a Period of Real and Nominal Uncertainty, July 2003

995 M. Hashem Pesaran, Til Schuermann, Björn-Jakob Treutler, and Scott M. Weiner, Macroeconomic Dynamics and Credit Risk: A Global Perspective, July 2003

996 Massimo Bordignon and Sandro Brusco, On Enhanced Cooperation, July 2003

997 David F. Bradford, Addressing the Transfer-Pricing Problem in an Origin-Basis X Tax, July 2003

998 Daniel Gros, Who Needs Foreign Banks?, July 2003

999 Wolfram Merzyn and Heinrich W. Ursprung, Voter Support for Privatizing Education: Evidence on Self-Interest and Ideology, July 2003

1000 Jo Thori Lind, Fractionalization and the Size of Government, July 2003

1001 Daniel Friedman and Donald Wittman, Litigation with Symmetric Bargaining and TwoSided Incomplete Information, July 2003

1002 Matthew Clarke and Sardar M. N. Islam, Health Adjusted GDP (HAGDP) Measures of the Relationship Between Economic Growth, Health Outcomes and Social Welfare, July 2003 